\title{
THE ANALYSIS OF ORGANIZATIONAL CULTURE VALUES IN PUBLIC SECTORS IN LATVIA
}

\section{Maija Ivanova, Irēna Kokina}

(1) Daugavpils University, Faculty of Education \& Management, Latvia

(2) Daugavpils University, Faculty of Education \& Management, Latvia

Maija Ivanova

Daugavpils University, Faculty of Education \& Management, Latvia, maija-ivanova@inbox.lv

Article info

Paper category: Preliminary paper

Received: 16.8.2016.

Accepted: 24.11.2016.

JEL classification: $\mathrm{D}_{21}, \mathrm{D}_{2} 3, \mathrm{M}_{51}$ 


\section{ABSTRACT HEADING}

Organizational culture is an important issue because of its 'big influence on enterprises' productivity and consequently on realization of their objectives and goals. The validation and harmonization of organizational values and employees' values has an important role in increasing operational efficiency. It has long been established that enterprises and organizations, where creative and interested employees who support and understand the organizational values of the company work, operate more effectively. In this article elements of organizational culture are studied with a particular focus on the meaning of organizational culture values. This article also reveals an evaluation of the organizational culture in public sectors in Latvia (based on publicly available data and sources of information). In the research there is an indepth analysis of official public organizational culture values included. The analysis has been done in the context of rating different leaders' organizational values. In this article we analyze the conclusions of various writers on the subject of organizational culture framework characterization. The research of values guidance as well as a view of cultural meaning and influence on both individual and organizational development is described here. The authors analyze the results of empirical research about official public values of companies and the results of a public leaders' survey (as well as the personal values of employees) which provide an opportunity to compare organizational employees'values with the common results of organizations. Conclusions shows public characterization of values and values distribution in potentially limitative and positive values. The in-depth research of organizational values is based on A. Maslow's (Maslow 2000) hierarchy of needs approach and developed on R. Barrett's (Barrett 2006) sample of seven levels of consciousness.

\section{Keywords:}

cultural entropy; organizational culture values; personal employee's values 


\section{INTRODUCTION}

Organizational culture is a hot topic because of its great impact on company productivity and goal realization. Today it is recognized that companies who employ those who understand, support and reconcile organizational values with their own personal values operate more effectively.

Organizational culture is significant in the development of an organization because the values uniting an organization and its employees contribute to its development. The detection of organizational and employees values (as well as awareness and harmonization of them) are a largely hidden part of the culture of a work environment.

Culture is a complex phenomenon and, as Dubkevics (2009) suggests, it comes about in the process of socialization and in a particular environment: it is not genetically inherited and its ambiguity is confirmed by large amounts of different definitions - according to Renge (2007) 250 different definitions of culture have been identified. Culture can be explained from philosophical, political, sociological and many other different points of view. Latvian philosophers Maija Kule and Rihards Kulis (1998:35) emphasize that "there is no such field of human existence, such a form of behavior to which the word "culture" could not be added".

The majority of authors on the subject (Schein, 1985; M. Vēbers, 1994; Cameron and Quinn, 1999; Praude and Belcikovs, 2001; Reṇge, 2007; Dāvidsone, 2008; Dubķēvičs, 2009) define organizational culture as a set or a system of common values, assumptions and cognitive systems that characterizes an organization, its managers and employees.

Leadership development professor Manfred Kets de Vries (2001) in his book "The Leadership Mystique" writes about culture as a system of values which affects every individual`s character, behavior, style of decision making and leadership style.

Dutch psychologist Gert Hofstede (Hofstede and Hofstede, 2005) defines organizational culture as the daily life of an organization, the set of values, traditions and rules that make up understanding of the power holding the organization together.

Recently the reduction of staff turnover in organizations has become a relevant issue. One of the most successful solutions for this problem is in the study of employees`values because it provides managers with information directly from employees: from those at whom decisions of the administration are aimed.

The objective of the study is to analyze and research significance of organizational culture values and to define the level of organizational culture entropy in organization $X$. 


\section{PERSONAL AND ORGANIZATIONAL CULTURE VALUES IN ORGANIZATION $X$}

As it has been shown in many surveys a large part of modern society does not trust public authorities. That is why this article looks at personal and organization culture values in public sector organizations and analyses them in order to assess interaction between personal values, stated values and the actual values of organization.

German philosopher F. W. Nietzsche indicates that values are the largest quantity which can be arrogated by a person (Niče, 2008:267). The value systems developed gradually and, in addition, every society had its own culture and its own dominant system of values.

In attempting to explain the existence of the world and the meaning of life in their treatises, ancient Greek philosophers also interpreted values. Plato (2006) emphasized that there is no perfection in the world but that one ought to strive for it as eternal values must be maintained. Such values as honesty, compassion and kindness have survived through the centuries and are core values today.

Latvian values are brightly depicted in Latvian folklore, which remains an important part of Latvian identity even today.

Latvian folklore urges us to do good deeds for other people and encourages everyone to join to the regimen of good works doers: it chimes with A. Maslow`s (2000;1998) and R. Barrett's (2008;1998) theory. Richard Barrett (Barrett, 2008) has suggested The Seven Levels of Consciousness model which is based on Maslow`s (Maslow, 2000) hierarchy of needs. American psychologist A. Maslow (2000) had a non-traditional approach: he tried to understand human nature without going into various pathologies. Maslow (Maslow, 2000) studied mature, successful, satisfied and happy people concluding that everybody is able to be such: this is the reason why in the hierarchy of needs the main accent is placed on human needs. The most important things to which a person is moving are their goals and beliefs.

When speaking about the significance of organizational values in achieving the goals of an organization we should not forget how important it is that employees accept these values, through which a high level of loyalty in the working environment in can be reached.

Green (Grīns, 2008) acknowledges that the work and the task themselves stimulate employees natural motivation rather than mere materialism, as sometimes people mistakenly believe. Studies show that in most cases people do not work because of material remuneration, except in the cases when the person is located on the lowest part of income scale. An employee works in order to demonstrate their professional skills, to certify themselves in society, to receive satisfaction, assessment, all because work is associated with the most important thing for a person - with value. 
Davidsone (2008) accentuates that in both levels - in individual and in organizational - values perform three basic functions:

- values are the driving force of motivation;

- values determine samples of desired individual and organizational behavior;

- values set standards which are used in evaluation of individual or organizational behavior.

By clarifying individual and organizational values it is possible to build mutual benefit based employment relationships. If the work in an organization corresponds to the employees' value system, they obtain significant or meaningful work. At the same time organizations obtain loyal employees who are willing to survive shortterm crisis and major changes together with the organization (Dāvidsone, 2008).

Realization of organizational values is an understanding about organizational culture and values, as well as about social, political and economical aspects that contribute in achieving results (Boitmane, 2006).

When defining the values in general, these are the principles and standards, which form the basis for decision-making, judgement and selection of action occur (Van der Wal et al., 2006).

In the context of organizational values there are regulatory guidelines, that determine desired attitudes and behavior, creating the moral basis for goals and activities (Christensen et al., 2007).

Organizational values are the deepest, non-visible layer of organizational culture, they can be open and hidden. Open or declared values are usually defined at the managerial level of an organization. They are included in organization documents, as well as occasionally reflected in short slogans and phrases which defines objectives and the nature of an organization. But organizational values, which as mentioned can be slogans and mottos, do not always reflect the true values of an organization. Sometimes they are hidden in the rush to profit, the non-recognition and hiding of failures, spying on competitors etc.

Values are the driving force that determines the desirable model, standard of behavior for individual or organization.

In the modern political and economic environment public authority organizations have to be able to respond rapidly to the changes in society and in the world, as well as being able to compete with the private sector for limited human resources and talents in the labor market.

Thus, the public sector starts to inherit those values that so far were more allocated to the private sector - innovations, efficiency, productivity.

The OECD states one of the main challenges facing the public sector is the need to find a balance between two sets of values. On the one hand such values as efficiency and productivity are the ones which should be implemented and developed, but on the other hand, there are traditional ones as democratic, morally ethical and peopleoriented values which are characteristic to public authority organizations and need to 
be saved. The integration of both sets of values is indispensable for public authorities in order to increase their competitiveness and the ability to react dynamically to the changes, but at the same time their core values should not be compromised (OECD 2009).

\section{RESEARCH METHODS AND PARTICIPANTS}

Lots of scientists have studied issues of organizational culture, providing us with important scientific insights, (Cameron \& Quinn, 1999; Kets de Vries, 2001; Barrett, 2008). In this study in depth research of organizational culture values is viewed based on R. Barrett's "Seven Levels of Consciousness method".

R. Barrett underlines the significance of creating a value-oriented organizational culture and offers the conception of transformation for entire culture system.

A high level of cultural entropy characterizes the culture of inflexible and weak organization (Barrett, 2008). If the level of organizational culture entropy is high, then elasticity in organization is low. Cultural entropy is an issue of values influenced by four factors: personal contradictions, structural contradictions, contradictions in values and contradictions in mission awareness. Cultural entropy is the proportion of all votes cast for potentially limiting values. The level of cultural entropy is calculated as follows - the number of votes for potentially limiting values divided by the number of votes given for all values and multiplied by 100 .

In the middle of $20^{\text {th }}$ century American psychologist A. Maslow (1998; 2000) invented his Hierarchy of Needs theory. Maslow`s (1998; 2000) theory is widely used in business, management and marketing in order to stay oriented to clients and customers ' needs. The basic thesis of this theory detects the motivation of people, as the causes of conflicts often lie in dissatisfied needs, the theory is also often used in conflictology. A. Maslow arranged human basic needs in five hierarchical levels, starting with the lowest - physiological, the second - safety, the third - love, belonging, the fourth - the basic need of self-esteem and ending with the highest level of needs - need of self-actualization. In R. Barrett's (2008; 1998) theory the first, second and third level corresponds to the first, second, third and fourth level of Maslow`s (1998; 2000) Hierarchy of Needs, and Barrett`s (2008; 1998) fourth, fifth, sixth and seventh level corresponds to Maslow`s need of self-actualization level.

This model is based on seven stages of personal development. Each stage has an actual, vitally important need, which corresponds to a particular situation and is the main motivating force. The lowest or basic needs (1. - 3. Level) apply to our physical survival, physical and emotional security, and emotional self-esteem. While the "highest" needs (5. - 7 . Level) are mental and apply to finding the meaning of life, transforming the world and service. In the first tree levels the personal benefit is dominant, and all the needs of a person 's ego are satisfied. In the three highest levels the needs of a person's soul is satisfied. The fourth level is a level of transformation, because within 
it a shift between personal benefit and common wealth happens. Seven vital needs are depicted in Figure 1. "Seven Levels of Personal and Organizational Consciousness".

Figure 1.: Seven Levels of Personal and Organizational Consciousness

\section{Seven levels of Personal Consciousness}

Leading a life of selfless service

Making a positive diference in the world

Finding a Personal Meaning in Existence

Finding freedom by letting go of our fears about survival, feeling loved, and being respected by our peers

Feeling a sense of personal selfworth

Feeling safe, respected, and loved

Satisfying our physical needs

\section{Seven Levels of Organizational Consciousness}

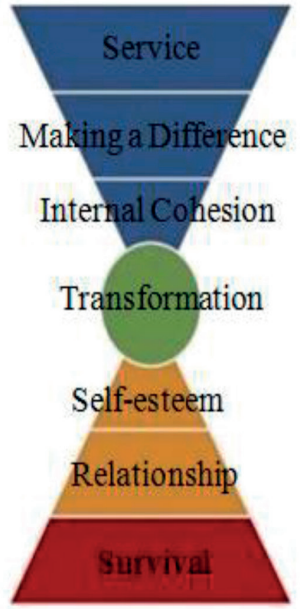

Service to humanity and the planet

Collaborate with others, build wider strategic alliances

Common visions, missions and basis of values

Involve members of the group and give them voting rights in decision-making

Ensure external dignity and internal pride

Build harmonic internal relations

Create the conditions necessary for security

Source: Barrett (1998)

R. Barrett s "Seven Levels of Consciousness" model can be applied to a person, groups of people or organizations. R. Barrett s "Seven Levels of Consciousness" model is used to create diagnostics for organizational culture. Cultural transformation instruments (Cultural Value Assessment, CVA) are used to make diagnostics of organizational culture. CVA is based on the concept that any style of behavior refers to one of the seven levels of consciousness.

Namely, each level of consciousness corresponds to certain values. Besides all values are divided in two categories - positive $(\mathrm{P})$ and potentially limiting (L). Table 1. shows the breakdown of values / styles of behavior in positive (P) and potentially limiting (L) according to seven levels of consciousness.

Table 1.: The compliance of values / styles of behavior with the levels of consciousness

\begin{tabular}{|c|c|c|c|}
\hline Level & Motivation & Positive Values (P) & LimitingValues (L) \\
\hline 7 & Service & $\begin{array}{r}\text { Social responsibility, } \\
\text { future generations, } \\
\text { compassion }\end{array}$ & - \\
\hline 6 & Making a Difference & $\begin{array}{r}\text { Mentoring, volunteer } \\
\text { work, environmental } \\
\text { awareness }\end{array}$ & - \\
\hline 5 & Internal Cohesion & $\begin{array}{r}\text { Trust, commitment, } \\
\text { honesty, integrity, } \\
\text { enthusiasm }\end{array}$ & - \\
\hline
\end{tabular}




\begin{tabular}{|c|c|c|c|}
\hline Level & Motivation & Positive Values (P) & LimitingValues (L) \\
\hline 4 & Transformation & $\begin{array}{r}\text { Adaptability, } \\
\text { continuous learning, } \\
\text { accountability }\end{array}$ & - \\
\hline 3 & Self-esteem & $\begin{array}{r}\text { Productivity, } \\
\text { efficiency, } \\
\text { professional growth }\end{array}$ & $\begin{array}{r}\text { Bureaucracy, } \\
\text { arrogance, image, } \\
\text { information hoarding }\end{array}$ \\
\hline 2 & Relationship & $\begin{array}{r}\text { Open communication, } \\
\text { customer satisfaction, } \\
\text { conflict resolution }\end{array}$ & $\begin{array}{r}\text { Blame, internal } \\
\text { competition, rivalry, } \\
\text { manipulation }\end{array}$ \\
\hline 1 & Survival & $\begin{array}{l}\text { Financial stability, } \\
\text { profit, employee health }\end{array}$ & $\begin{array}{r}\text { Control, chaos, } \\
\text { caution, job security }\end{array}$ \\
\hline
\end{tabular}

Source: Barrett (2008)

CVA is used to detect and to assess:

- personal values of members of the organization;

- current organizational values in perception of members of the organization;

- desired organizational culture values from the point of view of members of the organization.

The assessment of personal consciousness, current culture and desired culture is made not only in the organization as a whole, but also in constituent demographic categories. In order to create an appropriate list of values from all values possible, the adapted cultural values templates for evaluation of cultural values are composed at the very beginning.

When the template of personal values and organizational values is made, as well as the list of demographic categories, the next step is creating a tool for online survey, using which employees will be able to give their assessment of cultural values.

In order to obtain the data necessary for assessment, the survey respondents are asked to evaluate which of the values corresponds to employees ' personal values, current values organizational values and desired organizational values the best.

Evaluation and analysis of the data obtained in survey provides us with an insight into compliance of employees ' personal values with the current cultural values of the organization and conformity of current cultural values to desired cultural values.

At the same time data processing and analysis allows to define the level of cultural entropy in the organization. Barrett defines Cultural Entropy as: a proportion of the ener$g y$, which is wasted by organization or any group of people in unproductive activities, for example, bureaucracy, internal competition, "the construction of the Empire" etc. (Barrett, 2008:2)

The level of cultural entropy indicates either a healthy functioning of the organization, or shows that some minor or even major improvements are necessary. The detailed explanation of the meaning of the level of cultural entropy as well as recommendations for advisable actions are given in Table 2. "Significance of Different Levels of Cultural Entropy". 
Table 2.: Significance of Different Levels of Cultural Entropy

\begin{tabular}{|c|c|}
\hline Cultural entropy & Implications \\
\hline$\geq 4,0 \%$ & $\begin{array}{r}\text { Critical Issues-Requiring cultural and structural } \\
\text { transformation, selective changes in leadership, } \\
\text { leadership mentoring, leadership coaching, and } \\
\text { leadership development }\end{array}$ \\
\hline $3 \circ-39 \%$ & $\begin{array}{l}\text { Serious Issues-Requiring cultural and structural } \\
\text { transformation, leadership mentoring, } \\
\text { leadership coaching, and leadership development }\end{array}$ \\
\hline $20-29 \%$ & $\begin{array}{r}\text { Significant Issues-Requiring cultural and } \\
\text { structural transformation and leadership } \\
\text { coaching }\end{array}$ \\
\hline $10-19 \%$ & $\begin{array}{r}\text { Minor Issues-Requiring cultural and/or } \\
\text { structural adjustment }\end{array}$ \\
\hline$<10 \%$ & Prime-Healthy functioning \\
\hline
\end{tabular}

Source: Barrett (2008)

As the organizational culture in public sector organizations in Latvia has not been studied from value perspective, Barrett 's "Seven Level of Consciousness method" is chosen as the most appropriate to achieve the aim of the study. Empirical data collection and survey is carried out in this study and in order to compile the collected data the statistical data processing is used.

The question of this study:

- What is the level of cultural entropy in public organization X?

- What are the personal values of employees?

- Do the employees personal values in public organization X correspond to managers opinions about values necessary to the employee?

The object of the study: organizational culture values in public administration organizations.

The following tasks were defined in this study:

(1) to analyze declared values in public sector organizations in Latvia with the aim of identifying dominant values and characteristic values of institutions on the basis of publicly available data and information sources.

(2) To study and to analyze declared values in public administration of organization $X$, harmonization of organizational culture values and personal values of employees to identify positive and potentially limiting values and to evaluate level of entropy in organization.

This research is based on 64, public authorities and one public administration organization which have 30 departments in different regions of Latvia. Within the study were 56 different levels of executives (6 men and 5 o women) and 271 employees of public administration organization (27 men and 244, women) were surveyed. The average age of respondents: executives, $5^{3}$ years; average years of service in current organization, 17 years; average age of employees, 42 years; average years of service in current organization, 11 years. 


\section{RESULTS OF THE RESEARCH}

By analyzing the data about declared values in the public sector in Latvia using statistical method it was concluded, that 64 institutions in total have declared $5^{8}$ differing values. Thirty-three of all the values declared by all organizations are values determined as characterizing and were pointed out by just one participating institution. This suggests that these declared values are specific and related to the institution 's functions. 12 of the values are specific in two to three organizations. Three of the values are inherent in five to seven institutions. Ten of the values are inherent in more than ten organizations and are dominating values.

While analyzing the content of declared values, a surprising fact that came to light was that "Clients' satisfaction" was declared only by three organizations. Also of note was that the values do not cover the full spectrum of values, for example, there are no values defined in Survival level.

It is the reason why the overall impression was formed that for institutions the process of defining the value is completely formal, as it does not reflect today's innovations and possibilities.

Although in the public sphere public authorities are often criticized for insufficient availability of information to the public, while carrying out this study, in $92 \%$ of cases information about declared values was published on the authority 's website, ensuring that everybody is able to get acquainted with the declared values of the public authority. By doing this what actions and attitude can be expected by employees and society, and what atmosphere is created in workplace is readily identifiable.

The ten most frequently mentioned values are shown in Figure 1. "Declared values in public authorities", according to percentage breakdown.

Figure 1.: Declared values in public authorities

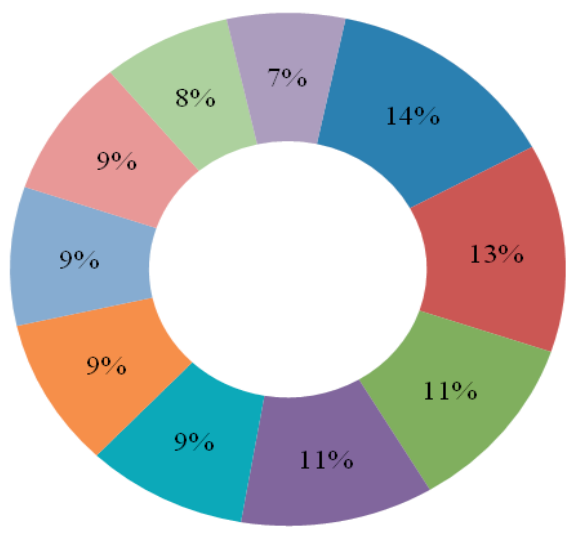

- Objectivity

- Loyalty

Frankness

- Justice

- Integrity

n Professionalism

- Confidentiality

- Independence

- Responsibility

- Neutrality

Source: the authors`calculations based on publicly available data 
The most classical values were Objectivity, Frankness, Justice, Integrity, Professionalism and Independence, but such values as Legality, Honesty, Equality, Collegiality, Purposefulness and Accuracy were also often declared in public organizations. Among less frequently mentioned values there were such values as Reliability, Tolerance, Striving to be better, the Succession and Self-support.

Declared values are specific as they are focused on a wide range of the public and may not reflect all of the values of the organization, however, following the formal approach of public authorities it denies them the opportunity to use values as a tool for development within the organization.

Managers of those organizations should pay more attention to organizational values, in order to strengthen and maintain or, if necessary, change them. The aim of every public authority is to strengthen exactly the values that actually will guide the organization to progress and will successfully repel all external threats and pressures.

Within the study about the values of public organization $\mathrm{X}$ a survey was carried out in which different level managers and employees of the public authority were asked to make an assessment of values. Managers separately highlighted current organizational values and desired personal values of employees, and employees of the public organization separately accentuated current organizational values and their personal values.

A summary of the results of this survey is arranged in levels according to $R$. Barrett`s Seven Levels of Consciousness Method. R. Barrett's (Barrett, 2008) method has an original approach, which allows us to analyze personal values of employees in organizations, organizational cultural values and transformation of culture, aloof which provide an assessment of values.

Organizations, which want to achieve success maintaining vitality have to acquire all seven levels of consciousness - the first - level of Survival, the second - level of Relationship, the third - Self-esteem level, the fourth - level of Transformation, the fifth - Internal Cohesion level, the sixth - level of Making Difference and the seventh - Service level. 
Figure 2.: Breakdown of values in public organization $X$

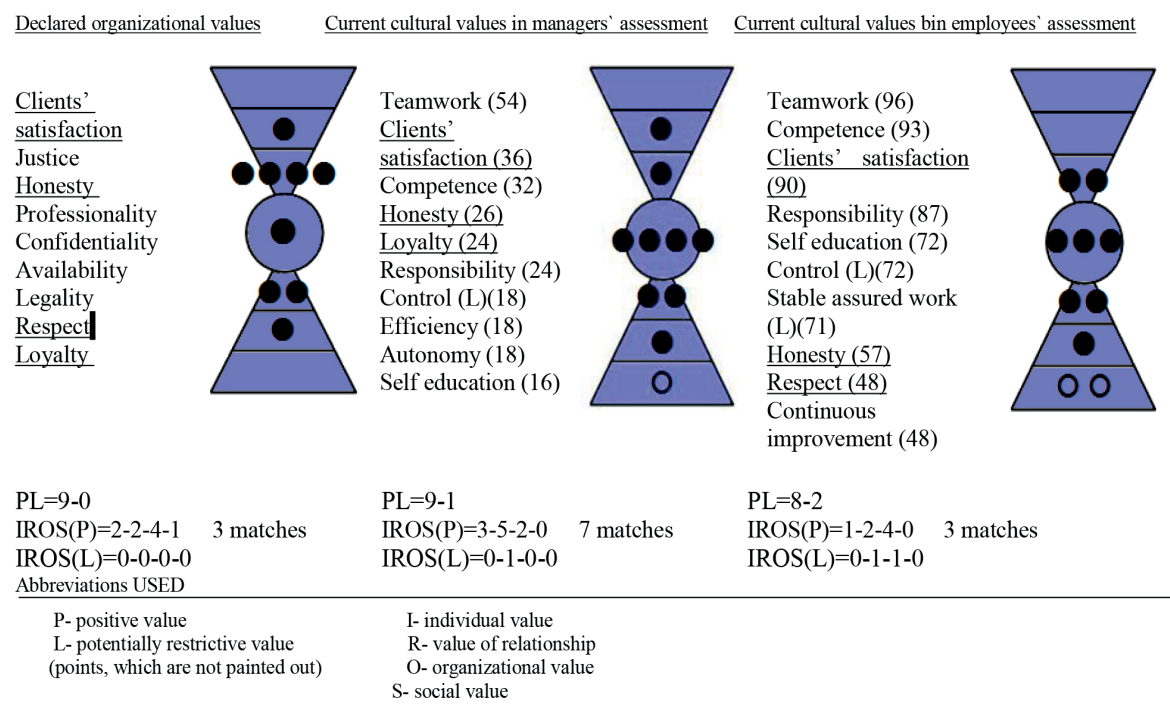

Source: authors'

Current cultural values and declared values of public organization $\mathrm{X}$ are shown in Figure 2. The values are arranged according to the number of votes (number in brackets after each value). Each shaded circle represents one of the positive values, each unfilled circle represents one of the potentially restrictive values obtained the biggest number of votes. Barrett (2008) points out, that potentially restrictive values appear in organization only then, when managers and ordinary employees act managed by their own ego and start to become a threat to common wealth.

By analyzing the results, it can be concluded, that there exists conformity between declared and current cultural values within managers`and employees`assessment, there are three matches of values in assessment given by managers - Clients satisfaction, Honesty and Loyalty, and by employees - Clients`satisfaction, Honesty and Respect, so it can be concluded, that employees and managers of public organization are aware of declared values, they have accepted them and know, what actions and attitude they are entitled to expect from each other and what atmosphere is created in the workplace.

One of the most positive results of the value assessment is that there are seven value matches between employees`and managers` assessment of current cultural values, six of which are positive values - Teamwork, Clients`satisfaction, Competence, Responsibility, Self education, Honesty - and one potentially restrictive value - Control. These systems of values show that managers and employees see their organization relatively equally, as well they show the fact, that both groups assessed the values of their organization objectively. However, potentially limiting value - Control - can testify to the fact, that this public authority has exaggerated monitoring, pro- 
cedure control, prudence, as well as tendency to avoid risk; as a result, employees do not feel confident about their future. Relatively similar distribution of the values on the level of transformation indicates that teamwork and communication skills are promoted in organization, and there is strong focus on improvement of processes. Transformation points to the changes, in result of which the structure of organization and procedures change, the responsibilities of employees and managers change, but it does not mean, that the whole team of organization is oriented to the same goal, and that's the reason why the transition to the fifth level - Internal Cohesion - is necessary. As Barrett (2008) points out the main objective of fifth level of consciousness is to join together in unified culture and to develop collective capacity.

Figure 3.: Breakdown of values in public organization $\mathrm{X}$

Desired values of employees from managers' point of view

Teamwork (51)

Responsibility (42)

Honesty (30)

Clients' satisfaction (42)

Self education (26)

Competence (24)

Employees' health (24)

Loyalty (22)

Autonomy (20)

Trust (20)

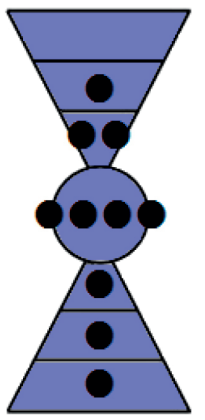

$\mathrm{PL}=10-0$

$\operatorname{IROS}(\mathrm{P})=3-5-2-0$

$\operatorname{IROS}(\mathrm{L})=0-0-0-0$

Values of employees working in public administration

Honesty (75)

Teamwork (75)

Trust (69)

Self education (66)

Friendship (66)

Clients' satisfaction

63)

Responsibility (60)

Counselling (54)

Patience (48)

Efficiency (45)

$\mathrm{PL}=9-1$

$\operatorname{IROS}(\mathrm{P})=3-5-2-0$

$\operatorname{IROS}(\mathrm{L})=0-1-0-0$

Abbreviations USED

$\mathrm{P}$ - positive value

L- potentially restrictive value

I- individual value

(points, which are not painted out)

R- value of relationship

$\mathrm{O}$ - organizational value

S- social value

Source: authors'

The breakdown of values according to the "seven levels of consciousness" is deployed in Figure 3. done in order to represent what values managers want to see in their employees and if these values comply with the values of current employees.

By analyzing the results, it can be concluded that desirable values of employees within managers 'assessment almost cover the full spectrum, and it shows that professionalism and qualification of managers in this organization are on a high level. They are able to transform organizational culture in a way which leads to successful and effective functioning.

The set of values on the fourth level shows that both managers and employees have reached such a level of consciousness that allows striving for transformation of the organization and it can be concluded that there is a very high conformity between desirable values of employees and personal values of employees, that is to say, there 
are six matches of values - Honesty, Teamwork, Trust, Responsibility, Clients`satisfaction, Self education.

Overall employees of this organization have the values which managers would like to see in their employees. However, employees do not act as if managed by the full spectrum of consciousness.

The level of cultural entropy in the organization describes the amount of energy which is spent inefficiently by employees and the organization as a whole.

The level of cultural entropy in public sector organization X is shown in Figure 4. Barrett (Barrett 2008) recommends certain models of action which should be chosen by an organization when it has reached a certain level of entropy. If the level of entropy is up to $10 \%$ then the organization is able to function healthily but if the level reaches $20 \%$, the organization has to take serious decisions as such a level of entropy indicates the need for cultural and structural transformation.

Figure 4.: Level of cultural entropy in organization X (\%)

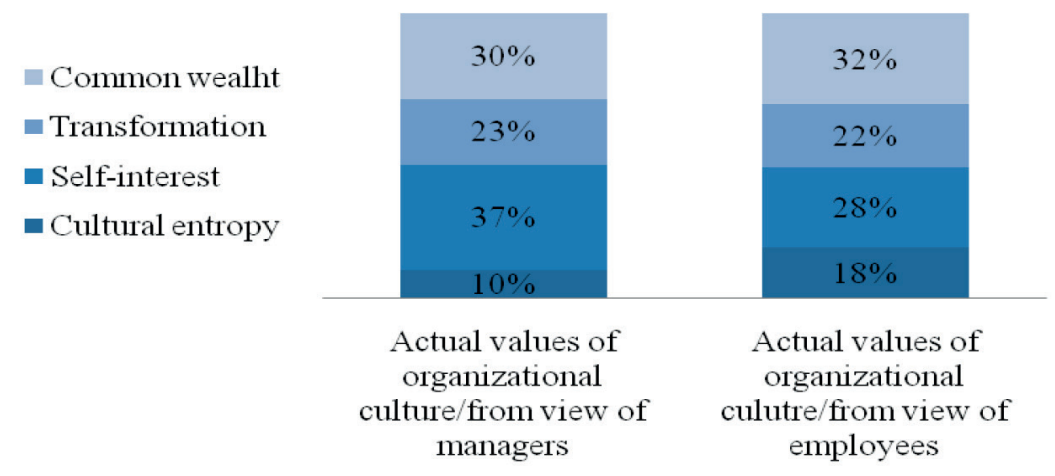

Source: authors'

By analyzing the assessment of organizational values given by the organization's managers and employees it is obvious (Figure 4.) that assessment is relatively similar in the level of Transformation and Common wealth, but the level of Self-interest and Cultural entropy is different. In assessment of managers, the level of cultural entropy is $10 \%$, but in the assessment of employees it is $18 \%$. According to results obtained it is possible to conclude that public authority organization $\mathrm{X}$ has to solve organizational issues - changes in organizational culture are needed. The organization has to revise its structure, tasks of departments, and responsibilities, as well as to focus on vales that are essential to employees. The results showed that there are pressing and important values for employees of public authority organization $X$ at the Survival level which managers must not ignore. In order to compare the level of entropy and the level of cultural entropy of current 
values, the desired values of employees and employees ' personal values in public organization $\mathrm{X}$ will be inspected.

Figure 5.: Level of cultural entropy in organization X (\%)

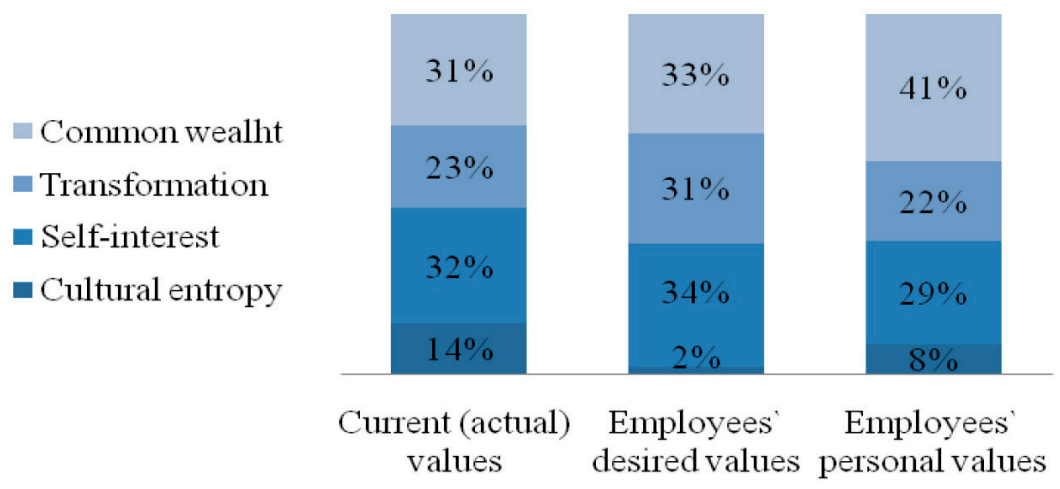

Source: authors'

By analyzing personal values of employees it is obvious, that employees ' personal values are coherent to organizational values (as it is seen in Figure 5.). The share of employees' personal values in the level of Common wealth is the highest when compared to the assessment of other two value categories.

The employees have reached a high level of consciousness because Common wealth is rated at $41 \%$ (Transformation - at $22 \%$, Self-interest - at $29 \%$ ). The level of cultural entropy is $8 \%$ and this assessment confirms that it is necessary to make corrections to meet the basic needs. The breakdown of values in public organization X: level of Common wealth - 31 $\%$; Transformation - $23 \%$, Self-interest - $32 \%$. The level of cultural entropy though is at $14 \%$. This clearly indicates the need to solve current issues - corrections in cultural structure or meeting other needs are necessary.

Employees` desired values divides as follows: level of Common wealth - 33\%; Transformation - 31\% Self-interest - $24 \%$. However, level of cultural entropy is $2 \%$. This means that by selecting employees with such values healthy functioning of organization would be ensured. As it can be seen, the level of current cultural entropy in public organization $\mathrm{X}$ is higher, that is why managers should strive towards reinvigoration of these values in their organization. 


\section{CONCLUSION}

(1) The results of the study show that managers of the organization realize and are able to define the personal values of employees which are essential to reach the goals of the organization. Analysis of the results of the survey show when desired values of employees and managers correlate, the level of cultural entropy can be low $(2 \%)$ and in such a way the optimal functioning of the organization can be ensured.

(2) The results of the research showed that current values of public organization $\mathrm{X}$ do not cover the full spectrum, which indicates that learning, training and experience are needed to act in the full spectrum of levels of consciousness. Potentially restrictive values indicate that energy is possibly being used inefficiently in controlling and monitoring and as a result employees are unable to express their creativity and they do not feel secure about their future. In its turn, the fact that the current level of cultural entropy is significantly (by $12 \%$ ) higher, indicates that managers use available resources and tools insufficiently. Managers should bring to life all the values which ensure that the organization is able to operate for a common future, common wealth and with the unifying goal where common values serve as the guide in decision making and set the limits of responsible freedom.

(3) The research about declared values in the public sector reveals one significant deficiency - there are not any declared values in the survival level and service level in public administrations. It is one of the ways in which it is possible to develop, taking into account the fact that organizations work most successfully when their values cover the full spectrum of the levels of consciousness model.

(4) The results of the study of public organization X could hereafter help to set priorities in work, to improve relationship between managers and employees, to help managers in making rational well-considered decisions about employees and in the development of the organization, as well as helping with improvement of mutual communication and drawing up of strategy.

(5) Personal values of the employees are broadly consistent with managers' opinions on values which are required for employees. However, the results of this research highlighted a peculiar inadequacy. Managers have chosen the value Loyalty - for them it is important that employees are loyal to the organization - but employees haven 't stated such a value at all. We can look at it from two different perspectives. From one side it is related to managers ' fear of losing talented employees, but from other side that communication is not successful enough. The management has to commit itself to improving the quality of communication and decision making. In this way they will be able to contribute to the loyalty of employees. This will give a chance to develop new ideas 
and to implement reforms which are necessary to improve the performance of the organization. In order to ensure that initiated reforms and direction of the development are implemented successfully it is recommended to make a periodical reevaluation of the level of cultural entropy in the organization. 


\section{REFERENCES}

Barets, R. "Vēertīborientētas organizācijas izveide." R̄̄ga: Domas spēks 24 (2008): 32

Barrett, R. "Liberating the Corporate Soul: A values-driven approach to building a visionary organization." (1998)

Boitmane, I. "Personāla atlase un novērtēšana." Rīga: SIA Lietišķāas informācijas dienests (2006)

Cameron, S. K. and Quinn, R. E., ,Diagnosing and Changing Organizational Culture Based on Values Framework" Addison-Wesley Publishing Company. Inc. (1999)

Christensen, Tom, Per Lžgreid, Paul G. Roness, and Kjell Arne Røvik. Organization theory and the public sector: Instrument, culture and myth. Routledge, 2007

Dāvidsone, G. "Organizāciju efektivitātes modelis." Rīga: SLA ODA 30 (2008)

Dubkēvičs, L. „Organizācijas kultūura”, Rīga: Jumava, (2008)

Grīns, E. "Efektīva personiskā saziņa sabiedriskajās attiecībās", Rīga: SIA Lietišķās informācijas dienests' (2008)

Hofstede, G. \& Hofstede, G.J. „Cultures and Organizations: Software of the mind“ New York: McGraw Hill, (2005)

Kets deVries, M.F.R. „The Leadership Mystiqe“, London: Financial Times/Prentice Hall, (2001)

Kūle, M.\& Kūlis, R. „Filosofija", Rīga:Zvaigzne ABC, (1998)

Maslow, A.H. „The Maslow Business Reader“ (Ed: Deborah Stephens) NY: Wiley, (2000)

Maslow, A.H. „Maslow on Management" NY: Wiley, (1998)

Nīče, V.F. „Varasgriba“" Mégininājums pārvērtēt vērtības. Rīga: Intelekt, (2008)

OECD. 2009. Government at a glance 2009. Paris: OECD Publishing.

Platons, Dialogi. Līsids. Harmids. Alkibiads pirmais. Hipijs Mazākais. No sengrieḳu valodas tulkojis $\bar{A}$. Feldhūns. - Rīga: Zinātne, (2006)

Praude, V. \& Belččikovs J. „Menedžments. Teorija un prakse“ Otrais pārstrādātais izdevums.- Rīga: Vaidelote, (2001)

Reņge, V. „Mūsdienu organizāciju psiholoǵija“. Rīga: Zvaigzne, (2007)

Schein, E.H. „Organizational Culture and Leadership“ San Francisco:Jossey-Bass, (1985)

Van Der Wal \& Huberts, L.\& Van den Heuvel, H., \& Kolthoff, E., Central values of government and Business: Diff erences, similarities and conflicts. Public Administration Quarterly, 3०(3/4), (2006): 314-364

Вебер, М. „Избранное“, Москва: Юрис, (1994)

Direct administration institutions` database. [viewed on April 11th, 2016]. Available from: http://tpi. mk.gov.lv/ui/ 